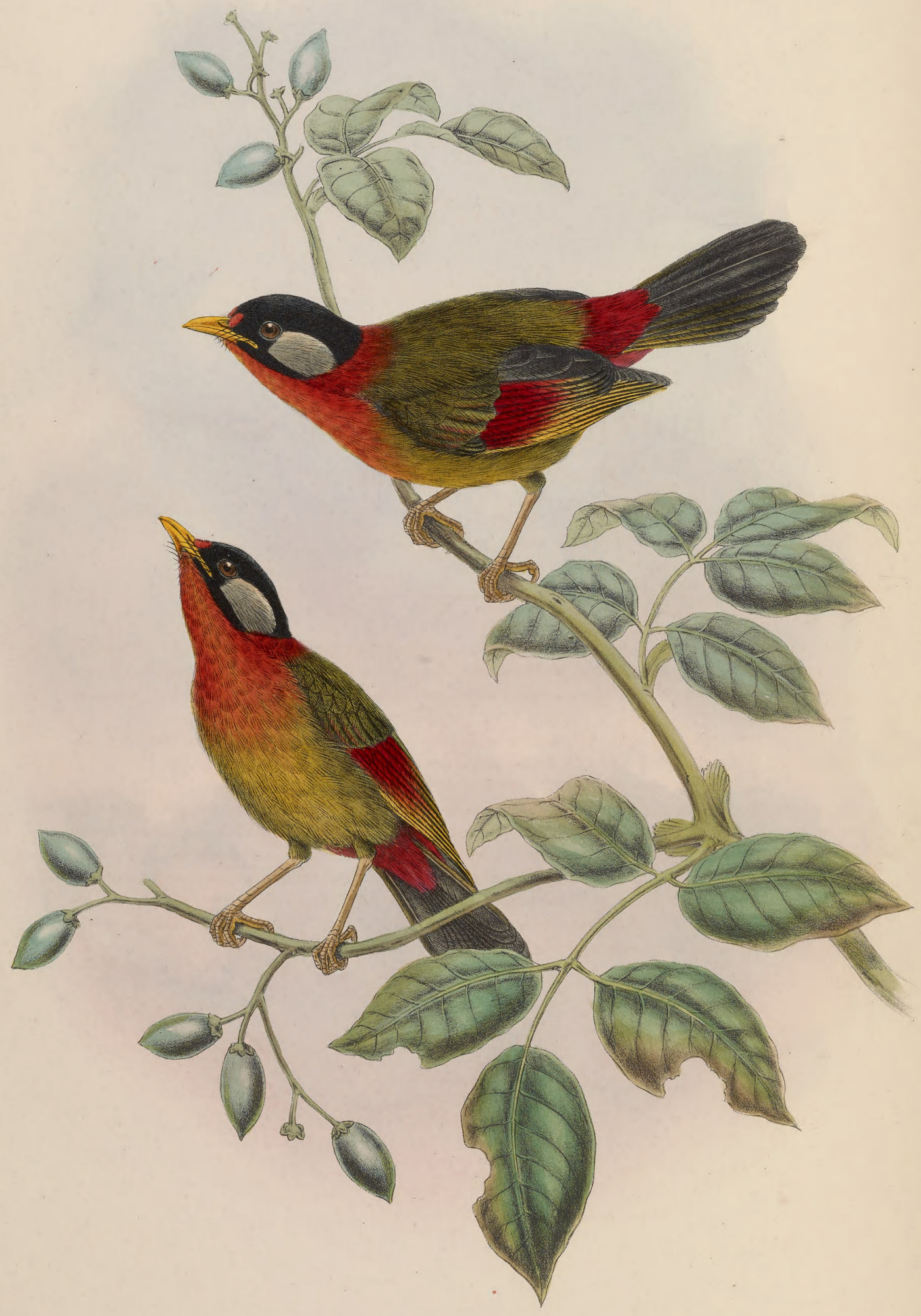




\title{
LEIO'THRIX LAURIN A, Salvad.
}

\author{
Marchioness Doria's Hill-Tit.
}

Leiothrix laurina, Salvad. Ann. Mus. Civic. Genov. xiv. p. 231 (1879).

Thrs beautiful species was discovered by Dr. Beccari during his expedition to Sumatra in 1878 . Ten specimens were obtained, all of them on Mount Singalan; and it is somewhat extraordinary that such a very conspicuous species should not have been discovered by any of the travellers who had previously visited Sumatra.

It is of the same form and style of coloration as Leiothrix argentauris of the Himalayas; but it is easily distinguished by the richer coloration on the throat and breast, which are crimson.

The following is a translation of Count Salvadori's description :-

Forehead, throat, neck all round, upper tail-coverts, and a large patch at the base of the quills blood-red; crown, lores, fore part of cheeks, and a line at the base of the lower mandible jet-black ; ear-coverts silvery grey; back and rump olive; breast and abdomen olive-yellowish ; wing-coverts olive like the back ; quills blackish, edged towards the tips with orange, edged at the base with blood-red, the innermost dusky, uniform ; tail black, the two outermost feathers edged externally with yellow; bill orange-yellow ; feet pale ; iris brown. I am indebted to Capt. Wardlaw Ramsay for the loan of a pair of birds, received by him from the Genoa Museum, thus enabling me to give a life-sized figure of the male and female birds. 


\section{$2 \mathrm{BHL}$ Biodiversity Heritage Library}

Gould, John. 1883. "Marchioness Doria's Hill-Tit, Leiothrix laurinre, Salvad. [PI. 17]." The Birds of Asia 4(XXXV), -. https://doi.org/10.5962/p.323188.

View This Item Online: https://www.biodiversitylibrary.org/item/120503

DOI: https://doi.org/10.5962/p.323188

Permalink: https://www.biodiversitylibrary.org/partpdf/323188

\section{Holding Institution}

Smithsonian Libraries

\section{Sponsored by}

Smithsonian Institution Libraries

\section{Copyright \& Reuse}

Copyright Status: Not in copyright

This document was created from content at the Biodiversity Heritage Library, the world's largest open access digital library for biodiversity literature and archives. Visit BHL at https://www.biodiversitylibrary.org. 